УДК 8.03

DOI 10.33514/1694-7851-2019-2-157-162

Рысманов Тыныбек Орозбекович

Старший преподаватель кафедры Музыки КГУ им. И.Арабаева

МУЗЫКА ТАРЫХЫНДА ЖАНА ПЕДАГОГИКАДА П.И. ЧАЙКОВСКИЙДИН

ЧЫГАРМАЛАРЫНЫН БААЛУУЛУКТАРЫ

ТВОРЧЕСКИЕ ПРОИЗВЕДЕНИЕ П.И. ЧАЙКОВСКОГО КАК ЦЕННОСТЬ

В ИСТОРИИ МУЗЫКИ И ПЕДАГОГИКИ

\title{
CREATIVE WORK OF TCHAIKOVSKY AS A VALUE IN THE HISTORY OF MUSIC
} AND PEDAGOGY

Аннотация: П.И. Чайковскийдин музыкалькк чьгармалары (1840-1893) өзүнүн маани-мазмундары боюнча кенен мүмкүнчүлктөрдөгү жанрларды камтып, адамзаттын аңу-сезимдик дүйнөсүндөгу туюмдардын тереңинде жаткан психо-эмочиооналдык баалуулуктарын альп чыгат.

Анын музыкалык чыгармаларындагы таасирлерден улам, адамдар өз ички дүйнөсүндө тынымсыз жүрүп турган өз ара карама-каршылыктагы өтө курч драманы камтыган кагылышуулардын дүйнөсүнө сүнгуп киргендей ааламдарга баргандай болот.

П.И.Чайковскийдин эмгектерин музыканын педагогикасынын тарыхындагы феноменалдуулук катары баалоонун эн негизги өзгөчөлүгү,-бул Россия элдеринин арасында эле эмес дүйнө элдеринин арасында да белгилүY бийик бааланган даражаларга жетүҮсу экендиги.

Композитор, симфонияльк чыгармалардыл лирикалык жанрдагы эмгектер катары баалаган, ал эми өз кезегинде мындай баа берүY ошол доордун жаңылыьгы катары белгиленген.

Анын чыгармалары адамзаттын өз тагдырына баш ийбей, түбөлүктүҮ болгон күрөшүүлөрдөн чыкпаган өмүр жолдору, сулуулук менен сокур ишенимдин ортосундагы аяоосуз салгылашууларын жалпы жамат жана журтчулукка жарыялагандай таасирлерин калтырат

Аннотация: Музыка Чайковского (1840-1893) охватывает широкий круг жанров, раскрывающих глубинные психологические прочессы человеческой души посредством их остродраматических внутренних столкновений. Феномен композитора заключался в том, что его музыка пользовалась огромной популярностью при жизни не только в России, но и за рубежом.

В наши дни интерес к ней не угасает, реализуя мечту композитора о о том, чтобы росло число людей, неравнодушных кего творчеству.

Композитор относился к симфонии как жанру лирическому, что было для его времени необычным. Именно здесь сформировались основные образы и идеи его творчества, пронизывающие всю музыку: противостояние душевной красоты, человечности и неизбежности, рока, слепой силь ненависти. Между этими крайними силами находится смятенный, ищущиий человек, тщуетно пытающийся победить роковую предопределенность.

Abstract: Tchaikovsky's Music (1840-1893) covers a wide range of genres, revealing the underlying psychological processes of the human soul through their ostrodramaticheskih internal clashes. The phenomenon of thecomposer was that his music enjoyed great popularity in life, not only in Russia but also abroad. art in our days it is not quenched, realizing the dream of the composer on that growing numbers of people who are not indifferent to its creativity. The composer treated the Symphony as the lyrical genre, what was for his time an unusual. It is here that formed the main images and ideas of his creativity, penetrating all music: soulful beauty, 
humanity and inevitability, rock, the blind forces of hatred. Between these extreme forces is smjatennyj looking for people futilely attempting to defeat a fatal predestination.

"Creative work of Tchaikovsky as a value in the history of music and pedagogy."

Ачкыч сөздөр: Музыка, история, педагогика, композитордук, драма, опера, педагог, дирижёр, балет, симфония, гармония, теория, оркестр, коом, чыгармачылык, искусство.

Ключевые слова: Музыка, история, педагогика, композиторское, драма, опера, педагог, дирижёр, балет, симфония, гармония, теория, оркестр, общество, произведение, искусство.

Keywords: Music, history, pedagogy, composition, drama, Opera, teacher, conductor, Ballet, Symphony, harmony, theory, Orchestra, society, work, art.

Пётр Ильич Чайковский. Родился 25 апреля (7 мая) 1840 года в Воткинске, Вятская губерния, Российская империя - умер 25 октября (6 ноября) 1893 года в Санкт-Петербурге. Русский композитор, дирижёр, педагог, музыкально-общественный деятель, музыкальный журналист. Считается одним из величайших композиторов в истории музыки.

Автор более 80 произведений, в том числе десяти опер и трёх балетов.

«Его концерты и другие произведения для фортепиано, семь симфоний (шесть пронумерованных и симфония «Манфред»), четыре сюиты, программная симфоническая музыка, балеты «Лебединое озеро», «Спящая красавица», «Щелкунчик», более 100 романсов представляют чрезвычайно ценный вклад в мировую музыкальную культуру». [1] Пётр Ильич Чайковский родился в селении при Камско-Воткинском заводе Вятской губернии (ныне город Воткинск, Удмуртия). Его отец - Илья Петрович Чайковский (17951880) - выдающийся русский инженер, был сыном Петра Фёдоровича Чайки, который родился в 1745 году в селе Николаевка Полтавского полка, близ г. Полтавы.

Его мать играла на фортепиано и пела, в доме стоял механический орган оркестрина, в исполнении которого маленький Пётр впервые услышал «Дон Жуана» Моцарта. Пока семья жила в Воткинске, им часто доводилось слышать по вечерам мелодичные народные песни рабочих завода и крестьян. В 1849 году семья переехала в город Алапаевск, а в 1850 году - в Санкт-Петербург. Чувствуя себя низшими по статусу из-за скромного происхождения, в 1850 году родители отправляют Чайковского в Императорское училище правоведения, находившееся вблизи от улицы, ныне носящей имя композитора. Чайковский провёл 2 года за границей, в 1300 км от родного дома, так как возраст поступления в училище составлял 12 лет. Для Чайковского разлука с матерью была очень сильной душевной травмой.

В 1852 году, поступив в училище, он начал серьёзно заниматься музыкой, которую преподавали факультативно. Чайковский был известен как неплохой пианист и хорошо импровизировал. С 16 лет начал уделять большее внимание музыке, занимаясь у известного педагога ЛуиджиПиччоли. Затем наставником будущего композитора стал Рудольф Кюндингер. Окончив училище в 1859 году, Чайковский получил чин титулярного советника и начал работать в Министерстве юстиции. В свободное от службы время посещал оперный театр, где на него сильное впечатление оказывали постановки опер Моцарта и Глинки. В 1861 году поступил в Музыкальные классы Русского музыкального общества (РМО), а после преобразования их в 1862 году в Петербургскую консерваторию стал одним из первых её студентов по классу композиции.

Его учителями в консерватории были Николай Иванович Заремба (теория музыки) и Антон Григорьевич Рубинштейн (оркестровка). По настоянию последнего он бросил службу и целиком отдался музыке. В 1865 году окончил курс консерватории с большой серебряной медалью, написав кантату на оду Шиллера «К радости»; другие его консерваторские работы - увертюра к пьесе Островского «Гроза» и танцы сенных девушек, включённые впоследствии в оперу «Воевода». 
«По окончании консерватории, по приглашению Николая Рубинштейна, переехал в Москву, где получил место профессора классов свободного сочинения, гармонии, теории и инструментовки в только что основанной консерватории. В 1868 году впервые выступил в печати как музыкальный критик и познакомился с группой петербургских композиторов - членов «Могучей кучки». Несмотря на разность творческих взглядов, между ним и «кучкистами» сложились дружеские отношения». [2]

У Чайковского проявляется интерес к программной музыке, и по совету главы «Могучей кучки» Милия Балакирева он пишет увертюру-фантазию «Ромео и Джульетта» по одноимённой трагедии Шекспира (1869), а критик В. В. Стасов подсказал ему замысел симфонической фантазии «Буря» (1873). В том же году познакомился с Дезире Арто. Он посвятил ей Романс ор. 5 и, как утверждается, закодировал её имя в текстах «Концерта для фортепиано с оркестром № 1» и симфонической поэмы «Фатум». Они планировали пожениться, но 15 сентября 1869 года Дезире неожиданно вышла замуж за испанского певца-баритона МарианоПадилью-и-Рамоса. Спустя 19 лет, в октябре 1888 года, Чайковский по просьбе Дезире написал Шесть романсов Ор. 65. 1870-е годы в творчестве Чайковского - период творческих исканий; его привлекают историческое прошлое России, русский народный быт, тема человеческой судьбы. В это время он пишет такие сочинения, как оперы «Опричник» и «Кузнец Вакула», музыка к драме Островского «Снегурочка», балет «Лебединое озеро», Вторая и Третья симфонии, фантазия «Франческа да Римини», Первый фортепианный концерт, Вариации на тему рококо для виолончели с оркестром, три струнных квартета и другие. К этому же периоду относится написанная по заказу организационного комитета Политехнической выставки кантата «В память 200-летия рождения Петра Великого» на слова Я. П. Полонского, она была впервые исполнена 31 мая 1872 года на Троицком мосту в Кремле под специально построенным навесом (дирижёр К. Ю. Давыдов, солист А. М. Додонов). С 1872 по 1876 год работал музыкальным критиком в газете «Русские ведомости», имевшей репутацию лево-либерального органа печати. В июле 1877 года, увлёкшись сочинением оперы «Евгений Онегин», импульсивно женился на бывшей консерваторской студентке Антонине Милюковой, которая была младше его на 8 лет. В силу различных обстоятельств супруги так и не смогли никогда развестись и жили раздельно. В 1878 году оставил пост в Московской консерватории и уехал за границу. Моральную и материальную поддержку ему в этот период оказала Надежда фон Мекк, с которой Чайковский в 1876-1890 годы вёл обширную переписку, но никогда не встречался. Фон Мекк посвящена одна из работ Чайковского этого периода - Четвёртая симфония (1877). В 1880 году за увертюру «1812 год» Чайковский получил орден Святого Владимира I степени.

В 1885 году его избирают директором Московского отделения РМО. Музыка Чайковского получает известность в России и за границей. С конца 1880 -х годов выступал как дирижёр в России и за рубежом.

Концертные поездки укрепили творческие и дружеские связи Чайковского с западноевропейскими музыкантами, среди которых - Ганс фон Бюлов, Эдвард Григ, Антонин Дворжак, Густав Малер, Артур Никиш, Камиль Сен-Санс и др. Весной 1891 года П. И. Чайковский совершает поездку в США. В качестве дирижёра своих произведений с сенсационным успехом он выступил в Нью-Йорке, Балтиморе и Филадельфии (подробное описание этого путешествия сохранилось в дневниках композитора).

В Нью-Йорке он дирижировал Нью-йоркским симфоническим оркестром на открытии Карнеги-холла. В последний раз в жизни Чайковский встал за дирижёрский пульт в Петербурге за девять дней до своей кончины - 16 октября (28 октября по новому стилю) 1893 года. Во втором отделении этого концерта впервые прозвучала его Шестая, «Патетическая» симфония. Последние годы своей жизни композитор провёл в окрестностях подмосковного города Клин, в том числе, в сохранившемся доме, где сейчас находится его музей. Ещё в 1873 г. в дневнике Чайковского во время поездки в 
Швейцарию появились строки: «Среди этих величественно прекрасных видов и впечатлений туриста я всей душой стремлюсь в Русь, и сердце сжимается при представлении её равнин, лугов, рощей...». С возрастом это чувство и стремление жить и творить вне городской суеты усиливались и 47-летний композитор написал: «Чем ближе подвигаешься к старости, тем живее чувствуешь наслаждения от близости к природе».

Не желая постоянно жить в Москве или Петербурге и не имея средств для покупки собственного жилья, «Чайковский искал для аренды дом в уединённом тихом месте Подмосковья, чтобы после утомительных гастрольных поездок иметь возможность полностью отдавать себя творчеству. Первый выбор пал на усадьбу Майданово неподалёку от Клина. 16 февраля 1885 г. он пишет Н. Ф. фон Мекк уже из «своего убежища»:

«Какое счастие быть у себя! Какое блаженство знать, что никто не придет, не помешает ни занятиям, ни чтению, ни прогулкам! ...Я понял теперь раз навсегда, что мечта моя поселиться на весь остальной век в русской деревне не есть мимолетный каприз, а настоящая потребность моей натуры». Дом стоял на высоком берегу реки Сестры в живописном парке. Близость железной дороги позволяла в любой момент по неотложным делам поехать в одну из столиц (в феврале 1885 г. Пётр Ильич был избран одним из директоров Московского отделения Русского музыкального общества). [3]

Каждый день с 9 до 13 часов Чайковский работал. После обеда в любую погоду уходил на двухчасовую прогулку с непременной записной книжкой для набросков музыкальных мыслей и тем. Соприкоснувшись с условиями жизни местных крестьян, композитор договорился с приходским священником, выпускником Вифанской духовной семинарии Е. С. Боголюбским об открытии в Майданове школы, на содержание которой жертвовал деньги. 24 июня 1885 г. композитор был очевидцем и даже помогал жителям в тушении пожара, уничтожившего в Клину полторы сотни домов и торговые ряды. Из Майданова Чайковский, по приглашению его ученика композитора С. И. Танеева, неоднократно ходил пешком в находившуюся неподалёку усадьбу Демьяново, которую в 1883 г. приобрёл философ и социолог В. И. Танеев. Чайковский прожил в майдановской усадьбе разорившейся помещицы, статской советницы Н. В. Новиковой с начала февраля 1885 г. до декабря 1887 г. Здесь он работал над новой редакцией оперы «Кузнец Вакула» («Черевички»), симфонией «Манфред», оперой «Чародейка» и другими произведениями.

ВоФроловском Чайковский написал увертюру «Гамлет», «Пятую симфонию», балет «Спящая красавица», оперу «Пиковая дама». К огорчению Чайковского, окружающий усадьбу лес, принадлежавший её хозяйке Л. А. Паниной, которая постоянно жила в Бессарабии, постепенно начал вырубаться. Дом ветшал и требовал средств на ремонт. С Фроловским пришлось расстаться. В мае 1891 г. композитор вернулся в Майданово, где прожил ровно год и где в этот период были написаны опера «Иоаланта» и балет «Щелкунчик». Из Майданова Чайковский переехал 5 мая 1892 г. в Клин в дом в самом конце города, на московском шоссе. Клинский период жизни композитора отмечен важными вехами международного признания его творчества: в ноябре 1892 г.

Чайковский был избран членом-корреспондентом парижской Академии изящных искусств, а в июне 1893 г. - почётным доктором Кембриджского университета. ВКлину он работал над окончательными корректурами партитур «Иоланты» и «Щелкунчика», создал многочисленные пьесы и романсы. Одно из последних написанных здесь произведений Третий фортепианный концерт датирован октябрём 1893 г. Здесь же в феврале - марте 1893 года была написана в эскизах и летом окончена инструментовка «Шестой симфонии», про которую композитор написал: «В симфонию эту я вложил без преувеличения всю свою душу». Чайковский продирижировал первым исполнением её 16 октября 1893 года в Петербурге, за несколько дней до смерти. И все таки не зря говорят в народе: «Искусство рождается из не искусства, образ в своих истоках не всегда оформлен рамками произведения». [4] 
Основные произведения Чайковского: Оперы Чайковского: Воевода (1868) Ундина (1869) Опричник (1872) Евгений Онегин (1878) Орлеанская дева (1879) Мазепа (1883) Черевички (1885) Чародейка (1887) Пиковая дама (1890) Иоланта (1891) Балеты Чайковского: Лебединое озеро (1877) Спящая красавица (1889) Щелкунчик (1892) Симфонии Чайковского: Симфония № 1 «Зимние грезы» ор. 13 (1866) Симфония № 2 op.17 (1872) Симфония № 3 op. 29 (1875) Симфония № 4 ор. 36 (1878) «Манфред» симфония (1885) Симфония № 5 (1888) Симфония № 6 ор. 74 (1893) Сюиты Чайковского: Сюита № 1 ор. 43 (1879) Сюита № 2 ор. 53 (1883) Сюита № 3 ор. 55 (1884) Сюита № 4 Моцартианаор. 61 (1887) Щелкунчик, сюита для балета ор. 71a (1892) Отдельные оркестровые произведения Чайковского: Торжественная увертюра на Датский гимн ор. 15 (1866) «Буря» ор. 18 (1873) Славянский марш (1876) ор. 31 «Франческа да Римини» симфоническая фантазия (1876)ор. 32 Итальянское каприччио ор. 45 (1880) Серенада для струнного оркестра ор. 48 (1880) «1812 год» - торжественная увертюра (1880)ор. 49 Гамлет, увертюра-фантазия, ор. 67, 1888 «Гроза», увертюра к драме ор. 76(1864) «Фатум» - симфоническая фантазия ор. 77(1868) «Воевода» симфоническая баллада ор. 78 (1891) «Ромео и Джульетта» - увертюра-фантазия $(1869,1870,1880)$ Марш Добровольного флота (1878) Марш Юрьевского полка (1893) Концерты Чайковского: Концерт № 1 для фортепиано с оркестром Концерт для фортепиано с оркестром № 1 ор. 23 (1875) Меланхолическая серенада ор. 26 (1875) Вариации на тему рококо для виолончели с оркестром ор. 33 (1878) Вальс-скерцо для скрипки с оркестром ор. 34 (1877) Концерт для скрипки с оркестром ор. 35 (1878) Концерт для фортепиано с оркестром № 2 op. 44 (1880) Концертная фантазия для фортепиано с оркестром ор. 56 (1884) Pezzocapriccioso для виолончели с оркестром ор. 62 (1887) Концерт для фортепиано с оркестром № 3 (1893) Фортепианные произведения Чайковского: Русское скерцо ор. 1, №. 1 (1867) Экспромт op. 1, o. 2 (1867) Воспоминание о Гапсале, 3 пьесы ор. 2 (1867) Вальс-каприс ор. 4 (1868) Романс ор. 5 (1868) Вальс-скерцо ор. 7 (1870) Каприччио ор. 8 (1870) Три пьесы ор. 9 (1870) Две пьесы ор. 10 (1871) Шесть пьес ор. 19 (1873) Шесть пьес на одну тему ор. 21 (1873) Большая соната соль мажор ор. 37a (1878) Времена года ор. 37b (1876) Детский альбом ор. 39 (1878) Двенадцать пьес ор. 40 (1878) Шесть пьес ор. 51 (1882) Думка ор. 59 (1886) Восемнадцать пьес ор. 72 (1893) Соната до-диез минор ор. 80 posth (1865, изд. 1900) Камерная музыка Чайковского: Струнный квартет № 1 ор. 11 (1871) Струнный квартет № 2 ор. 22 (1874) Струнный квартет № 3 ор. 30 (1876) «Воспоминание о дорогом месте», три пьесы для скрипки и фортепиано ор. 42 (1878) Фортепианное трио ор. 50 (1882) «Воспоминание о Флоренции», струнный секстет ор. 70 (1890) Хоровая музыка Чайковского: Всенощная для смешанного хора без сопровождения, ор. 52 Литургия для смешанного хора без сопровождения, ор. 41 Духовно-музыкальные сочинения на полный хор (1884-85): Херувимская песнь № 1 (1887)

\section{Список использованной литературы:}

1. Асафьев Б.В. Избранные труды. Т.ІІ. М.,1954. Стр.90.

2. Протопонов В. и Туманина Н. Оперное творчество Чайковского. М.,1957. Стр. 55.

3. Раабен Л. Скрипачные и виолончельные произведения П.И.Чайковског. М.,1958. Стр. 104.

4. Мигунов А.С. Искусство о процесс познания. М.,1986. Стр.82

5. Бортникова Е. Е; Давыдова К. Ю; Прибегина Г. А; ПротопоповиВ. В. Воспоминания о П. И. Чайковском .3-е изд.- М., 1979; 4-е изд.- Л., 1980. Стр.91.

Рецензент: к.ф.н., доцент Самыйканов А.Т. 